\title{
SUPERVISI DAN PERANANNYA PADA SEKOLAH DASAR
}

\author{
Nahdatul Hazmi \\ STKIP Abdi Pendidikan Payakumbuh \\ hazminahdatul@gmail.com
}

\begin{abstract}
ABSTRAK
Penelitian ini bertujuan untuk mengetahui peranan supervisi dalam mengembangkan kualitas guru dalam mengajar. Penelitian ini merupakan penelitian kualitatif dengan Subjek penelitian kepala sekolah dan guru. Hasil penelitian menunjukkan bahwa kepala sekolah dalam memimpin tidak mampu menegakkan aturan dan disiplin kepada semua guru, hanya mengikut kepada keputusan anggotanya. Ketika ada proses pembelajaran dan perangkat mengajar guru yang kurang tidak ada semacam sanksi atau teguran dari kepala sekolah, mengajar disekolah ini hanya mengikuti aturan masing-masing saja. Namun ketika ada sidak dari pengawas ataupun UPT baru ada komunikasi antar guru tersebut. Dengan Adanya rapat mendadak mengakibatkan terganggunya proses belajar mengajar, karena gurunya rapat membuat siswanya tidak ada yang mengawasi, sehingga siswa-siswa tersebut berkeliaran. Simpulan, pada akhirnya proses pembelajaran yang telah tersususun dengan baik di dalam perangkat pembelajaran tidak terlaksana dengan baik, karena guru yang mengajar akan mengejar jam pelajaran yang dipakai ketika rapat mendadak, akibatnya siswa akan kesulitan untuk memahami pelajaran yang diberikan guru tersebut.
\end{abstract}

Kata Kunci : Supervisi, Peran Kepala Sekolah

\begin{abstract}
This study aims to determine the role of supervision in developing the quality of teachers in teaching. This research is a qualitative research with the subject of the school principal and teacher. The results showed that the principal in leading was unable to enforce rules and discipline to all teachers, only following the decisions of their members. When there is a learning process and teaching devices that are lacking there is no sanction or reprimand from the school principal, teaching at this school only follows each other's rules. But when there is inspection from the supervisor or UPT there is new communication between the teacher. The existence of an unexpected meeting resulted in disruption of the teaching and learning process, because the teacher's meeting made the students did not supervise, so the students wandered. Conclusion, in the end the learning process that has been arranged well in the learning device is not carried out properly, because the teacher who teaches will pursue the hours of study used during a sudden meeting, as a result students will find it difficult to understand the lessons given by the teacher.
\end{abstract}

Keywords: Supervision, Role of School Principals 


\section{PENDAHULUAN}

Keberhasilan suatu sekolah pada hakikatnya terletak pada efektifitas dan efesiensi penampilan kepala sekolah. Kepala sekolah merupakan kunci utama dalam penyelenggaraan pendidikan di sekolah.Kepemimpinan kepala sekolah merupakan salah satu faktor yang dapat mendorong sekolah untuk dapat mewujudkan visi, misi, tujuan dan sasaran sekolah melalui program-program yang dilaksanakan secara terencana dan bertahap.

Di dalam Peraturan Mentri Pendidikan Nasioanal Nomor 13 Tahun 2007 tentang Standar Kepala Sekolahmenegaskan bahwa seorang kepala sekolah harus memiliki lima dimensi kompetensi minimal yaitu: kompetensi kepribadian, manajerial, kewirausahaan, supervisi dan sosial. Supervisi akademik yang dilakukan kepala sekolah terhadap guru-guru merupakan suatu hal yang perlu dilakukan, guna untuk meningkatkan profesionalisme guru. Supervisi itu sendiri adalah pengawas atau kepengawasan (Maryono, 2011), sedangkan supervisi pembelajaran sering diartikan sebagai serangkaiaan usaha bantuan kepada guru (Imron, 2011). Supervisi yang dilakukan berkaitan dengan proses pembelajaran yang dimulai dari perencanaan kemudian diwujudkan dalam pelaksanaan yang dilakukan guru hingga mencapai hasil pembelajaran.

Hasil pembelajaran akan baik apabila proses pembelajarannya dirancang dan dilaksanakan oleh guru dengan tepat pula, tetapi bukan hanya berdasarkan guru yang mengajar, motivasi dan peran kepala sekolah juga dituntut. Peran kepala sekolah tidak hanya sebagai pemimpin di sekolah tetapi juga berperan sebagai supervisor untuk membantu guru dalam meningkatkan kualitas belajarmengajar. Menurut Sahertian (2008) ada tiga pendekatan dalam melakukan supervisi pendidikan. Pertama, pendekatan direktif. Dalam hal ini supervisi memberikan arahan langsung kepada guru. Kedua, pendekatan non-direktif, yaitu supervisi tidak secara langsung menunjukkan permasalahan, tapi supervisi terlebih dahulu mendengarkan secara aktif apa yang dikemukakan oleh guru. Ketiga, pendekatan kolaboratif. Dalam hal ini supervisi dan guru bersama-sama bersepakat untuk struktur, proses dan kriteria dalam melaksanakan proses percakapan terhadap masalah yang dihadapi oleh guru. Permasalahannya ialah banyak kepala sekolah yang lebih mementingkan dokumen administrasi guru daripada masuk ke kelas untuk melakukan observasi terhadap guru mengajar. Akibatnya, guru jarang melakukan persiapan dalam mengajar dengan baik. Guru yang tidak pernah diobservasi dalam mengajar biasanya cenderung kurang memikirkan strategi dalam mengajar, metode yang digunakan masih menggunakan metode ceramah, dan kurang memperhatikan keterlibatan siswa dalam kegiatan pembelajaran. Padahal gaya mengajar yang lebih bervariasi dan mempersiapkan bahan ajar merupakan hal yang sangat mendukung dalam proses pembelajaran.

Di Sekolah Dasar Negeri 1 Kenagarian Labuh Gunuang, kepala sekolah yang berperan sebagai pemimpin dan supervisortidak terlihat pelaksanaan 
supervisi akademik yang dilakukan disekolah tersebut. Permasalahan yang ditemukan dilapangan, pertama,Justru yang terlihat dilapangan adalah kepala sekolah tidak melakukan kewajibannya dengan baik, disini kepala sekolah juga sebagai guru kelas dua. Seharusnya guru kelas yang bertugas mengajar memberikan pembelajaran dan mengevaluasi tugas-tugas peserta didik disekolah SD namun yang terjadi adalah si guru memberikan tugas tersebut kepada salah satu peserta didik untuk menilai tugas teman-temannya. Permasalahannya disini adalah ketika si peserta didik tersebut yang bertugas memberi nilai bertengkar dengan temannya maka nilai teman itu teracam walaupun tugas yang dibuat sudah benar. Kedua, si guru yang juga kepala sekolah tersebut sering terlihat tidak diruangan kelas ketika jam pelajaran berlangsung, bukan karena alasan sebagai kepala sekolah namun lebih banyak karena alasan lain. Ketiga, wibawa seorang kepala sekolah sering terlihat dilecehkan disini, seperti ada kebijakan yang diambil oleh guru lain yang tidak diketahui oleh kepala sekolah, kemudian juga sering terjadi perselihan antar guru yang tidak bisa diselesaikan oleh kepala sekolah sehingga guru memilih menyelesaikan masalah dengan melibatkan kepala UPT dinas pendidikan. Empat,kepala sekolah tidak mampu menegur guru yang membuat kesalahan, karena kalah pamor dengan guru tersebut atau takut memberi sanksi karena si guru "berkuasa"disekolah tersebut.Lima, kepala sekolah sebagai pemimpin tidak mampu memberi masukan kepada anggotanya atau guru sekolah untuk merubah atau meningkatkan kemampuannya dalam mengajar.

Walaupun ada beberapa guru kelas di sekolah ini telah melakukan variasi didalam proses belajar, namun masih terdapat guru yang mengajar dengan cara lama sehingga membuat siswa menjadi kurang aktif dalam proses pembelajaran. Jadi, untuk mengatasi atau menanggulangi hal tersebut sangat dibutuhkan peranan dari seorang supervisor untuk memberi masukan kepada guru dalam menciptakan proses belajar mengajar yang lebih baik, sehingga tidak hanya guru yang berperan aktif tetapi juga melibatkan siswanya.

Apabila proses belajar mengajar telah baik, maka nilai yang diperoleh siswa tentu baik pula, tetapi berdasarkan data yang diperoleh menunjukkan bahwa hasil ujian sekolah tahun 2014/2015 terjadi penurunan nilai-nilai mata pelajaran dari tahun sebelumnya. Berdasarkan hal tersebut penulis ingin meneliti permasalahan yang terdapat di sekolah dasar 01 Labuh Gunuang, apakah karena kurangnya peran kepala sekolah, gurunya yang kurang melakukan variasi terhadap metode dan model pembelajaran atau kurangnya pengawasan dari supervisor yang dalam hal ini adalah kepala sekolah.

\section{METODE PENELITIAN}

Metode penelitian yang digunakan dalam penelitian ini adalah menggunakan teknik pengumpulan data melalui metode kualitatif yang pada hakekatnya merupakan penelitian dengan mengamati orang dalam lingkungan hidupnya, berinteraksi dengan mereka, dan berusaha memahami bahasa dan 
tafsiran mereka tentang dunia sekitarnya. Dengan demikian, dalam metode ini peneliti harus turun kelapangan.

Observasi. Observasi adalah pengamatan langsung ke lapangan. Observasi dalam penelitian ini bergunan untuk mendapatkan dan mengumpulkan informasi dari pengamatan secara langsung. Observasi dilakukan untuk mendapatkan informasi tentang bagaimana peranan supervisi akademik terhadap guru mata pelajaran IPS.Pada penelitian ini, peneliti berpartisipasi secara pasif karena peneliti hanya mengamati dan tidak terlibat langsung dengan apa yang diteliti.

Wawancara. Wawancara adalah percakapan dengan maksud tertentu dan merupakan pengumpulan data yang banyak digunakan oleh penelitian karena dilakukan dengan tanya jawab langsung kepada informan. Wawancara yang peneliti lakukan adalah wawancara terstruktur yakni wawancara yang pewawancaranya menetapkan sendiri masalah dan pertanyaan-pertanyaan yang akan diajukan kepada informan dengan teknik snowball Question.

Studi dokumentasi. Studi dokumentasi berguna untuk melengkapi data-data yang telah diperoleh. Studi dokumentasi dilakukan untuk mengungkapkan data yang bersifat administratif serta kegiatan-kegiatan yang di dokumentasikan. Studi dokumentasi dilakukan untuk mengetahui hal yang berhubungan dengan data guru, data siswa serta hal lainnya yang dirasa perlu yang sudah di dokumentasikan.

Dalam penelitian ini analisis data yang digunakan adalah analisis data yang diuraikan oleh Miles dan Huberman. Miles dan Huberman mengemukakan bahwa aktivitas dalam analisis data kualitatif dilakukan secara interaktif dan berlangsung secara terus menerus sampai tuntas, sehingga datanya sudah jenuh. Aktivitas dalam analisis data ini terdiri atas tiga kegiatan yang terjadi secara bersamaan, yaitu: Reduksi data: meliputi proses memilih, menyederhanakan, menfokuskan, mengabstraksi dan mengubah data kasar ke dalam catatan lapangan; Penyajian data: yaitu merangkai data dalam suatu organisasi data, sehingga memudahkan untuk ditarik kesimpulan atau merumuskan tindakan yang diusulkan berdasarkan temuan penelitian; Penarikan kesimpulan: yaitu menjelaskan tentang makna data dalam suatu konfigurasi, sehingga dapat menunjukkan alur kausalnya.

\section{HASIL DAN PEMBAHASAN}

Pelaksanaan supervisi akademik pada dasarnya merupakan proses pembimbingan dari pihak atasan kepada guru-guru untuk meningkatkan kinerja guru yang dalam hal ini yaitu proses pembelajaran. Dengan demikian, esensi supervisi adakemik itu sama sekali bukan menilai unjuk kerja guru dalam mengelola proses pembelajaran, melainkan untuk membantu guru mengembangkan kemampuan profesionalnya.Dalam standar pelayanan minimal pendidikan dasar dinyatakan bahwa supervisi dilaksanakan minimal 2 kali dalam satu semester terhadap masing-masing guru. Oleh karena itu, setiap satuan pendidikan perlu menyusun program supervisi di awal tahun pelajaran, 
melaksanakan supervisi, menindaklanjuti hasil supervisi dan seterusnya membuat laporan pelaksanaan supervisi.

Pada SDN01 Kenagarian Labuh Gunuang, supervisi akademik belum bisa dilaksanakan disekolah ini karena adanya kevakuman kepala sekolah beberapa waktu yang lalu, kemudian sekarang jabatan kepala sekolah dipegang oleh plt kepala sekolah Erianti,S.Pd sudah lebih satu tahun belakangan ini. Seperti yang ditulis dipendahuluan bahwa wibawa kepala sekolah kalah pamor dengan guru honorer, sehingga supervisi belum bisa dilaksanakan disekolah ini seperti yang disampaikan plt kepala sekolah dalam wawancara,

"Sebenarnya supervisi akademik itu dilakukan 2 kali dalam satu semester sesuai dengan standar minimal. Sedangkan disekolah ini belum dapat melaksanakan oleh kami hanya yang dilakukan oleh pengawas saja baru. Sebenarnya supervisi belum dilaksanakan sudah agak lama mulai dari kepala sekolah lama (Syaruman), sekarang saya menjabat kepala sekolah namun saya belum bisa memutuskan kapan akan diadakan supervisi tunggu keputusan dari guru lain dulu”

Kurang maksimalnya pelaksanaan supervisi akademik di SDN 01 Labuh Gunuang ini disebabkan oleh beberapa hal, seperti banyaknya program lainnya yang harus dilaksanakan dan pelaksanaan supervisi telah termasuk ke dalam PKG (Penilaian Kinerja Guru), penjelasan ini dipertegas oleh Ibuk Fitrianis, bahwa:

"Supervisi akademik belum bisa dilaksanakan karena, 1) adanya kevakuman kepemimpinan, sehingga sulit dalam menetapkan waktu pelaksanaan supervisi, 2) banyaknya program sekolah lainnya, 3) pelaksanaan supervisi akademik itu telah dianggap inklup dengan $P K G$ ”

Dalam pelaksanaan Supervisi akademik dilaksanakan dengan tiga tahap, yaitu: 1) tahap pendahuluan, dimana pada tahap ini kepala sekolah, tim supervisi dan guru membicarakan rencana tentang materi observasi yang akan dilaksanakan. Tahap ini berhubungan dengan kelengkapan administrasi guru berupa RPP; 2)tahap observasi, yaitu guru melatih kemampuan mengajar berdasarkan komponen keterampilan yang telah ditetapkan pada tahap pendahuluan; 3) tahap evaluasi, yaitu tahap dimana guru diberi saran oleh tim supervisi mengenai apa yang perlu diperbaiki.

Dalam melaksanakan ketiga tahapan supervisi idealnya kepala sekolah membentuk tim Supervisor yang terdiri dari Kepala Sekolah dan dibantu oleh beberapa guru yang ditunjuk kepala sekolah. Tim supervisi yang telah terbentuk selanjutnya merumuskan tujuan supervisi akademik, menentukan indikator/sasaran supervisi akademik, dan membuat jadwal supervisi serta mempelajari instrumen supervisi yang akan digunakan dalam monitoring. Tim supervisi menuangkan rumusan tujuan, sasaran, jadwal dan instrumen pada 
dokumen program supervisi akademik. Dokumen tersebut akan menjadi dasar dan acuan kepala sekolah dan tim supervisi untuk melaksanakan supervisi akademik.

Setiap melakukan suatu kegiatan pasti mempunyai tujuan yang ingin dicapainya, begitujuga dengan pelaksanaan supervisi akademik di SDN 01 Labuah Gunuang. Adapun aspek-aspek yang disupervisi demi tercapainya tujuan tersebut adalah: 1) Perangkat pembelajaran, 2) Proses belaja mengajar dan 3) Tindak lanjut. Hal ini juga dipertegas oleh Ibuk Erianti selaku supervisor, seperti berikut:

“Dalam pelaksanaan supervisi terdapat tiga aspek yang menjadi penilaian. 1) kelengkapan perangkat yang dinilai ketika pra supervisi, 2) proses pembelajaran yang dimulai dari kegiatan pendahuluan, kegiatan inti dan kegiatan penutup, apakah sesuai dengan yang diterangkan pada RPP, 3)tindak lanjut, berupa pengarah, ada yang bersifat diskusi dan ada juga berupa pemberian contoh"

Hal serupa juga dijelaskan oleh ibuk Harmailis, sebagai berikut:

"Yang pertama itu adalah perangkat pembelajaran. kedua, pelaksanaan PBM (apakah sesuai/tidak antara apa yang dituangkan dalam RPP dengan proses pembelajaran yang sedang berlangsung, seperti penggunaan media, metode, kesesuaian waktu) dan ketiga adalah tindak lanjut"

Setiap aspek yang menjadi penilaian dalam supervisi akademik mempunyai poin-poin tertentu yang menjadi penilaiannya. Pertama, perangkat pembelajaran. Adapun yang menjadi penilaiannya adalah: 1) menentukan identitas mata pelajaran, 2) standar kompetensi, 3) kompetensi dasar, 4) indikator pencapaian kompetensi, 5) tujuan pembelajaran, 6) materi ajar, 7) alokasi waktu, 8) metode pembelajaran, 9) kegiatan pembelajaran, 10) penilaian hasil belajar, 11) sumber belajar.Jadi, kesimpulannya yang dinilai dalam perangkat pembelajan adalah semua hal yang tertuang dalam rencana pelaksanaan pembelajaran (RPP). Penyusunan RPP harus disesuaikan dengan silabus yang ditetapkan pemerintah.

Penyusunan RPP yang telah dibuat oleh guru di SDN 01 Labuah Gunuang telah berdasarkan silabus yang ada, tetapi terdapat beberapa item yang tidak sesuai. Ketidak sesuaian di sini yaitu antara apa yang ada di RPP dengan apa yang diterapkan oleh guru pada proses pembelajaran seperti alokasi waktu. Pembagian waktu merupakan hal yang penting, agar tujuan pembelajaran tercapai terutama untuk SD yang mempunyai materi banyak.

Permasalahan lainnya, yaitu dalam menerapkan metode pembelajaran, dimana ada beberapa guru yang dalam RPP tertera metode pembelajaran, seperti metode gambar tetapi pada proses pembelajaran metode tersebut tidak diterapkan. Metode yang sering digunakan guru dalam proses pembelajaran adalah ceramah dan tugas. 
Kedua, proses belajar mengajar. Adapun hal-hal yang nilai ada tiga tahap, yaitu:

Kegiatan pendahuluan; a) guru memberi apersepsi dan motivasi, b) guru memberi tahu kompetensi yang akan dicapai (tujuan pembelajaran)

Kegiatan inti; a) guru tampak kurang menguasai materi pembelajaran, b) guru mengelola kelas dengan baik, c) metode/pendekatan kurang variatif, d) guru menggunakan alat bantu/media pembelajaran (alat peraga, peta, dsb), e) guru berperan sebagai fasilitator dalam membantu mengatasi kesulitan peserta didik, f) guru menggunakan teknik bertanya dengan bahasa yang baik dan benar, g) peserta didik kurang berpatisipasi secara aktif dalam pembelajaran, h) pada pembelajaran tidak nampak ada proses eksplorasi dan elaborasi, i) peserta didik tampak kurang ceria dan antusias dalam belajar, j) ada penilaian untuk mengetahui pencapaian kompetensi (namun yang menilai tugas siswa adalah salah seorang siswa yang ditunjuk guru), k) pelaksanaan pembelajaran belum sesuai dengan RPP, 1) pembelajaran diselesaikan kadang tidak tepat waktu

Kegiatan penutup; a) guru membimbing peserta didik membuat rangkuman hasil pembelajaran, b) pemberian tugas untuk pertemuan berikutnya.

Dari yang diuraikan diatas dapat disimpulkan, bahwa pada proses belajar mengajar yang menjadi penilaian adalah berkaitan dengan tugas pokok guru yaitu memberikan pengajaran terhadap siswa melalui kegiatan belajar mengajar di kelas. Permasalahan yang tampak pada proses belajar mengajar di SDN 01 Labuah Gunuang, yaitu: 1) pada kegiatan pendahuluan yang sering dilupakan guru yaitu menyampaikan tujuan pembelajaran. 2) pada kegiatan inti yang jadi permasalahan yaitu penggunaan metode dan media yang kurang menarik mengakibatkan siswa tidak berpartisipasi secara aktif dan kurang antusias dalam mengikuti pelajaran. Guru masih kurang memanfaatkan teknologi informasi sebagai sumber belajar karena kekurangan sarana dan prasarana. Masih ada beberapa guru yang pelaksanaan pembelajaran tidak sesuai dengan RPP, yaitu dalam menerapkan metode pembelajaran. Penggunaan waktu belum sesuai dengan pengaturan waktu yang tertera pada kegiatan belajar-mengajar. 3) pada kegiatan penutup telah terlaksana bagaimana semestinya, yaitu guru membimbing siswa untuk merangkum pembelajaran yang telah dipelajari dan adanya pemberian tugas untuk pertemuan selanjutnya, seperti menyuruh siswa untuk membaca materi pertemuan selanjutnya di rumah.

Ketiga, Tindak lanjut. Setelah dilaksanakannya supervisi akademik akan diketahui dimana kelebihan dan kekurangan dari guru yang disupervisi. Para guru akan diberi arahan oleh tim supervisi ke arah yang lebih baik, seperti cara menggunakan metode pembelajaran yang sesuai dengan materi, cara membangkitkan semangat siswa agar aktif dalam belajar dengan cara diskusi. Selain pemberian saran dari tim supervisi, guru yang disupervisi juga dinilai apakah ada perubahan atau tidak. 
Permendiknas No. 19 Tahun 2007 tentang pengelolaan pendidikan menyatakan bahwa kepala sekolah sebagai pemimpin lembaga, wajib melaksanakan supervisi pembelajaran. Kepala sekolah SDN 01 Labuah Gunuang selain seharusnya sebagai supervisor, beliau juga seharusnya berperan sebagai ketua dalam tim supervisi. Agar kegiatan supervisi akademik dapat berjalan dengan baik dan lancar, kepala sekolah harus mampu menjadi pemimpin yang baik. Namun yang terjadi adalah plt kepala sekolah tidak mampu melaksanakan tugasnya tersebut, guru baru melengkapi perangkat mengajarnya ketika ada kunjungan dari pengawas. Dari hasil pengamatan penulis terlihat bahwa ada semacam suasana yang kurang kondusif di lingkungan sekolah ini, ada seorang guru honorer yang temperamen dengan "gaya preman" mengusai kebijakankebijakan sekolah sehingga kepala sekolah juga tidak "berkutik". Guru tersebut juga merupakan warga sekitar sekolah dan anak dari orang yang cukup disegani didaerah itu.

Pemimpin merupakan seseorang yang menjadi panutan atau contoh di dalam suatu organisasi atau kelompok dan mampu mempengaruhi, membimbing dan menggerakkan anggotanya untuk mencapai tujuan yang telah ditetapkan. Menurut Jejen Musfah pemimpin adalah seseorang yang mempunyai kemampuan untuk memengaruhi perilaku orang lain dalam kerjanya dengan menggunakan kekuasaan (Musfah, 2015).

Kepemimpinan yang baik dan tidak baik merupakan hal yang harus dipahami oleh kepala sekolah sebagai seorang pemimpin. Kepala sekolah harus memiliki strategi yang tepat untuk memimpin bawahannya dalam melakukan berbagai tugas dan fungsinya sebagai seorang pemimpin. Dengan memahami gaya kepemimpinan akan dapat meningkatkan pemahaman seorang kepala sekolah sebagai pemimpin sekolah terhadap dirinya sendiri, serta dapat mengetahui kelebihan dan kelemahan yang dimilikinya dan dapat meningkatkan pemahaman tentang bagaimana seharusnya memperlakukan bawahannya.Namun hal tersebut tidak berlaku di sekolah ini, karena kepala sekolah termasuk kepada tipe pemimpin laizes faire.

Berdasarkan pengamatan yang dilakukan, dapat dikatakan bahwa kepemimpinan kepala sekolah di SD Negeri 1 Kenagarian Labuah Gunuang dalam kategori kurang baik, tetapi walaupun kepemimpinan kepala sekolah kurang baik dan masih terdapat kelemahan dalam pelaksanaan proses pembelajaran, karena adanya kegiatan-kegiatan yang tidak terstruktur dari kepala sekolah, seperti adanya rapat dewan guru yang dilakukan secara mendadak. Namun sekolah ini sering dipakai sebagai tempat menyelengarakan acara-acara baik itu tingkat nagari maupun kecamatan, jadi ada nilai tambah untuk sekolah dalam hal dari segi pemanfaatan dan lingkungan serta lokasi sekolah yang stretegis dan luas.

Pelaksanaan supervisi akademik pada dasarnya bertujuan untuk membantu guru meningkatkan kemampuan profesionalnya dalam proses pembelajaran 
melalui pemberian bantuan yang bercorak layanan profesional (Imron, 2011), adapun tujuan dari pelaksanaan supervisi akademik yang dilakukan di SD Negeri 1 Kenagarian Labuah Gunuang seperti tertuang dalam program supervisinya adalah: 1) meningkatkan kompetensi guru dalam merencanakan dan melaksanakan proses pembelajaran di kelas, 2) meningkatkan menajemen dan administrasi guru, 3) meningkatkan layanan profesionalisme guru kepada peserta didik, 4) mengevaluasi kinerja guru dalam rangka pembinaan guru.

Dalam pelaksanaan supervisi akademik yang menjadi sasarannya adalah guru SDN 01 Labuah Gunuang yang berjumlah 7 orang termasuk kepala sekolah,dari datayang ditemukan permasalahan yang sering terlihat pada proses pembelajaran adalah kurangnya antusias siswa dalam mengikuti pelajaran. Hal ini disebabkan karena siswa kurang mendapat motivasi dari guru mengenai pelajaran yang sedang berlangsung. Kalau kepala sekolah melakukan supervisi maka guru akan mengetahui apa yang menjadi kekurangannya selama ini dalam hal pembelajaran, sehingga membuat guru akan berfikir kreatif dalam merancang proses pembelajaran agar siswa-siswa yang diajarkan lebih tertarik mengenai pengajaran yang sedang berlangsung. Namun hal itu tidak terjadi dan guru hanya melengkapi perangkat yang diperiksa oleh pengawas tapi alam PBM nya tidak ada yang berubah. Bahkan ditemukan dilapangan ada guru yang tidak disegani dan tidak dihargai oleh siswa dikelas, ketika si guru mengajar siswa banyak yang diluar atau tidak memperhatikan guru menerangkan. Hal ini tidak ada respon dari kepala sekolah sepertinya dibiarkan saja.

\section{SIMPULAN}

Berdasarkan hasil penelitian dengan mengacu kepada landasan teori yang digunakan, penelitian ini dapat disimpulkan bahwa pelaksanaan supervisi akademik di SD Negeri 1 Kenagarian Labuah Gunuang tidak berperan terhadap peningkatan kinerja guru, kepala sekolah dan tim supervisi, serta terhadap sekolah dalam peningkatan mutu sekolah.Dengan adanya supervisi akademik membuat guru mengetahui dimana kekurangan-kekurangannya, sehingga mengakibatkan proses pembelajaran kurang memotivasi siswa. Tidak dilakukannya supervisi akademik membuat kinerja guru sangat buruk dan menjadi buah bibir bagi masyarakat yang enggan menyekolahkan anaknya disana.

\section{DAFTAR PUSTAKA}

Imron, A. (2011). Supervisi Pembelajaran Tingkat Satuan Pendidikan. Jakarta: Bumi Aksara

Musfah, J. (2015). Manajemen Pendidikan "Teori, Kebijakan dan Praktik", Jakarta: Kencana

Maryono, M. (2011). Dasar-Dasar dan Teknik Menjadi Supervisor Pendidikan, Jogjakarta: Ar- Ruzz Media

Sahertian, P. A. (2000). Konsep Dasar dan Teknik Supervisi Pendidikan dalam Rangka Pengembangan Sunber Daya Manusia, Jakarta: Rineka Cipta 